15 Knott $C$, Williams CP, Reynolds $\mathrm{F}$. Phenytoin kinetics during pregnancy and the puerperium. Brf Obstet Gynaecol 1986;93:1030-7.

16 Paton RD, Logan RW. Salivary drug measurement: a cautionary tale. Lancet 1986;ii:1340.

17 Krauer B, Dayer P, Anner R. Changes in serum albumin and l-acid glycoprotein concentrations during pregnancy: an analysis of fetal-maternal pairs. Brf Obstet Gynaecol 1984;91:875-81.

$18 \mathrm{Nau} \mathrm{H}$, Luck W, Kuhnz W. Decreased serum protein binding of diazepam and its major metabolite in the neonate during the first post-natal week relate to increased free fatty acid levels. Br $\mathcal{F}$ Clin Pharmacol 1984;17:92-8.

$19 \mathrm{Nau} \mathrm{H}$, Helge H, Luck W. Valproic acid in the perinatal period: decreased maternal serum protein binding results in fetal accumulation and neonatal displacement of the drug and some metabolites. F Pediatr 1984;104:627-34.

20 Krauer B, Nau H, Dayer P, Bischoff P, Anner R. Serum protein binding of diazepam and propranolol in the feto-maternal unit from early to late pregnancy. $\mathrm{Br} \mathcal{F}$ Obstet Gynaecol 1986;93:322-8.

21 Mygind KI, Dam M, Christiansen J. Phenytoin and phenobarbitone plasma clearance during pregnancy. Acta Neurol Scand 1976;54:160-6.

22 Lander CM, Smith MT, Chalk JB, et al. Bioavailability and pharmacokinetics of phenytoin during pregnancy. Eur $\mathcal{F}$ Clin Pharmacol 1984;27:105-10.

23 Bardy AH, Teramo K, Hiilesmaa VK. Apparent plasma clearances of phenytoin, phenobarbitone, primidone and carbamazepine during pregnancy: results of the prospective Helsinki study. In: Janz D, Dam M, Richens A, Bossi L, Helge H, Schmidt D, eds. Epilepsy, pregnancy and the child. New York: Raven Press, 1982:141-5.

24 Richens A. Drug treatment of epilepsy. London: Henry Kimpton, 1976.

25 Hiilesmaa VK, Bardy A, Terano R. Obstetric outcome in women with epilepsy. Am $\mathcal{f}$ Obstet Gynecol 1985;152:499-504.

26 Dalessio DJ. Seizure disorders and pregnancy. $N$ Engl f Med 1985;312:559-63.

27 Nakane $Y$, Okuma T, Takahishi R, et al. Multi-institutional study on the teratogenecity and fetal toxicity of anti-epileptic drugs: a report of a collaborative study group in Japan. Epilepsia 1980;21:663-80.

28 Philbert A, Dam M. The epileptic mother and her child. Epilepsia 1982;23:85-99.

29 Yerby $M$, Koepsell T, Daling D. Pregnancy complications and outcome in a cohort of women with epilepsy. Epilepsia 1985;26:631-5.

30 Egenaes J. Outcome of pregnancy in women with epilepsy, Norway 1967-1978: description of material. In: Janz D, Dam M, Richens A, Bossi L, Helge H, Schmidt D, eds. Epilepsy, pregnancy and the child. New York: Raven Press, 1982:81-5.
31 Friis ML, Holm NV, Sindrup EH, Fogh-Andersen P, Hauge M. Facial clefts in sibs and children of epileptic patients. Neurology 1986;36:346-50.

32 Meadow SR. Anticonvulsant drugs and congenital abnormalities. Lancet 1968;ii: 1296.

33 Phelan MC, Pellock JM, Nance WE. Discordant expression of fetal hydantoin syndrome in heteropaternal dizygotic twins. $N$ Engl f Med 1982;307:99-102.

34 Hanson JW, Smith DW. The fetal hydantoin syndrome. F Pediatr 1975;87:285-90.

35 Strickler SM, Miller MA, Andermann E. Genetic predisposition to phenytoin-induced birth defects. Lancet 1985;ii:746-9.

36 Zackai EH, Mellman WJ, Neiderer B, Hanson JW. The fetal trimethadione syndrome. $\mathcal{F}$ Pediat 1975;87:285-90.

37 Meadow SR. The teratogenic associations of epilepsy and anticonvulsant drugs. In: Hopkins A, ed. Epilepsy. London: Chapman and Hall (in press)

38 Livingston J, Lyall H. Contribution of fetal alcohol syndrome to mental retardation. Lance 1986;ii:1337-8.

39 Lindhout D, Meinardi H. Spina bifida and in-utero exposure to valproate. Lancet 1984;ii: 396.

40 Hiilesmaa VE, Teramo K, Granstrom M-L, Bardy AH. Serum folate concentrations in women with epilepsy. BrMed f 1983;287:577-9.

41 Markestad T, Ulstein M, Strandjord RE, Aksnes L, Aarskog D. Anticonvulsant drug therapy in human pregnancy: effects on serum concentrations of vitamin D metabolites in maternal and cord blood. Am F Obstet Gynecol 1984;150:254-8.

42 Carriero R, Andermann E, Moy-Fung Chen MD, et al. Thyroid function in epileptic mothers and their infants at birth. Am $\mathcal{F}$ Obstet Gynecol 1985;151:641-4.

43 Davies VA, Argent AC, Staub H, et al. Precursor prothrombin status in patients receiving anticonvulsant drugs. Lancet 1985 ; $1: 126-8$.

44 Deblay MF, Vert $P$, Andre M, Marchal F. Transplacental vitamin $K$ prevents haemorrhagic disease of infant of epileptic mother. Lancet 1982;i:1247.

45 Bossi L. Neonatal period including drug disposition in newborns: review of the literature. In: Janz D, Dam M, Richens A, Bossi L, Helge H, Schmidt D, eds. Epilepsy, pregnancy and the child. New York: Raven Press, 1982:327-34.

46 Desmond MM, Schwanecke RP, Wilson GS, et al. Maternal bärbiturate utilisation and neonatal withdrawal symptomatology. F Pediatr 1972;80:190-7.

47 Kaneko S, Suzuki K, Sato T, Ogawa Y, Nomura Y. The problems of antiepileptic medication in the neonatal period: is breast feeding advisable? In: Janz D, Dam M, Richens A, Bossi L, Helge H, Schmidt D, eds. Epilepsy, pregnancy and the child. New York: Raven Press 1982:343-8.

48 Nau H, Cuhnz W, Egger HJ, Rating D, Helge H. Anticonvulsants during pregnancy and lactation. Clin Pharmacokinet 1982; 7:508-43.

\title{
Portraits from Memory
}

\section{7-Dr E C (Ted) Smith (d 1943)}

\author{
JAMES HOWIE
}

Ted Smith, a medical graduate of Dublin, was a first rate microbiologist; director of the Medical Research Institute at Yaba, Ebute Metta, Lagos, Nigeria; a real gentleman, a bachelor, a lover of animals, music, and flowers; and a most effective supporter of the British army pathologists who were posted to Nigeria during the period 1941-3.

I was in charge of the first of the laboratories that was set down in Nigeria as part of 56 General Hospital in Ibadan in May 1941. Very soon after my arrival I was summoned to a military-civilian conference in Lagos to discuss the problems that had arisen from the possibility that yellow fever might well be exported by aircraft from west Africa to Egypt and India, where the disease did not exist but the transmitting mosquito did. After the fall of France in 1940, and the failure in September 1940 to capture Dakar in French West Africa, the only means of rapid communication between Britain and Egypt and India was by air via Sierra Leone, the Gold Coast, Nigeria, and the Sudan or east Africa. The risk of spreading yellow fever by this air route was well understood and was guarded

\section{Edinburgh EH13 0BU}

SIR JAMES HOWIE, MD, FRCP

Correspondence to: 34 Redford Avenue, Edinburgh EH13 0BU. against by so called antiamaryl precautions worked out in the 1930 s by the League of Nations Health Organisation in Geneva. These precautions required the elimination of all mosquito breeding areas within a quarter of a mile range of airfield buildings and runways, that distance being regarded as the greatest a mosquito could fly. Yellow fever in an African could be a very mild infection so that a carrier state could not be excluded. No unimmunised person, therefore, was allowed within the antiamaryl area. So, the calculation went, no passenger or mosquito carrying the virus could reach Egypt, east Africa, or India by the air route. But runways up to 10 times the lengths originally legislated for made it impossible to keep the zone mosquito free. Moreover, the danger of enemy airborne invasion from adjacent Vichy French territories was a real threat and it became necessary to station unimmunised African troops on the four transAfrican airfields in Nigeria. Rotation of duties meant that these troops could come from any of the regiments scattered throughout that vast area-six times the size of England and Wales.

Knowing nothing about yellow fever except from textbooks, I was now called on to advise the military how best to respond to the urgent civilian representations that "something must be done." It seemed to me that, with plenty of energy and good organisation, it would surely be possible to immunise all the African troops who might be liable for airfield protection duty.

How little I knew of the vaccine, as I was promptly told. It was expensive and scarce, especially after the bombing of the one laboratory in England that could make it. Moreover, it had to be 
stored in powder form in ampoules kept at refrigerator temperature and used within one hour of its reconstitution in saline. It was so unstable that it was necessary to check for productin of antibodies in all of those inoculated to rule out the possibility that the vaccine might have failed to retain its antigenic properties. The conference broke up without a solution to the problem having been found.

\section{Infection with enthusiasm}

As I was leaving Smith came up to me. "Come home," he said, "let us get acquainted, and let us discuss your foolish suggestion. There might be just a possibility of doing something with the vaccine on the lines you suggested. Happily your ignorance of the vaccine allowed you to make a suggestion which none who knew its vagaries would have put forward."

He then told me how the Rockefeller Institute in New York had just produced a new batch of vaccine that might possibly be more stable than the existing one. If he could get supplies under lend lease would I think of taking it into the remote areas where it would have to be used? And would I be able to take a batch of very young mice and inoculate them intracerebrally after each inoculation session as a means of checking the potency of the vaccine at the time of use without the elaborate mouse protection tests for the presence of antibody in the blood of the inoculated people? This was a daunting programme, but Smith thought it might just be worth attempting; and so I said that I'd be glad to do whatever was required if he could convince the army headquarters in Accra and secure the vaccine. $\mathrm{He}$ did both in a remarkably short time, and the expedition and field work that followed from that will be told in the next portrait of Lieutenant Colonel Fred Murgatroyd, RAMC.

Smith then told me how he himself had arrived at Yaba in 1928 just as the Rockefeller Institute's yellow fever research was reaching its climax. Noguchi, working in the Panama Canal zone of South America, had isolated a microbe-which he named Leptospira icteroides-from patients sent to him diagnosed as having yellow fever. Only fantastically refined microscopy could distinguish between $L$ icteroides (Noguchi) and $L$ icterohaemorrhagiae, the accepted cause of leptospirosis. The Rockefeller people were not happy about Noguchi's results, considering that the clinicians who sent him patients were not experts in diagnosis, and they invited him to repeat his observations in Nigeria, where yellow fever abounded but, as it was then believed, leptospirosis was not present as it was in the Panama Canal zone. Noguchi-alas-could not find his $L$ icteroides in unquestioned cases of yellow fever in Nigeria. At the same time Stokes, an English microbiologist, not only put forward but, at Yaba, proved the case for yellow fever's being caused by a filter passing virus. His correct conclusion was sadly confirmed by his accidentally inoculating himself with blood during a postmortem examination of a patient with yellow fever. When Stokes himself died of yellow fever Noguchi saw that the case was proved. Noguchi, who had lost face, was a high caste Japanese and atoned by doing a postmortem examination on Stokes. He inoculated himself, perhaps not by accident, and died of yellow fever, thus completing the proof.

As Smith went over these tragic events-now part of history-he became keenly alive and enthusiastic about the possibility of taking the latest Rockefeller vaccine into use as an epidemiologically useful preventive agent on a vast scale. His enthusiasm certainly infected me. We became close friends in that moment.

\section{Blood money}

I had many other valuable meetings with Smith during the years 1941-3. We must have a survey, he said, to find out how much yellow fever there had been in Nigeria in the past 10 years. He had been pestering the education people to persuade young children to give blood for analysis but their responses were useless. Could I do this in Ibadan? Not through the useless education authorities but with help from the Mother Superior of the Roman Catholic convent, adjacent to the swamp in the centre of Ibadan where the sacred crocodile was accommodated. This was in fact easily accomplished when the request was backed by my offer of one penny (a real reward then) for every child offering blood. We had 10 children a day for the next 30 days. The pennies were collected from the children by their escorting novices and "donated"-at the children's expressed wish, so we were assured-to the church. So my staff and I gave a party at Christmas for the donor children. At the end of it the Mother Superior treated us to the stiffest glass of prime Scotch whisky that I have ever tasted. The survey showed that yellow fever was still a potential menace.

Smith also urged me to look hard for leptospires, which he could not believe were absent from Nigeria. We found them. He also told me that his laboratory was scheduled, by agreement with military headquarters, to supply all our laboratory needs. When I indented for media I should send him a carbon copy-not shown: a "blind" copy —of the indent that I sent to army headquarters. That way I should receive the supplies by return instead of six weeks later. Smith knew the realities of communication in Nigeria. There seemed to be nothing that he had not thought of, and that was indeed true. He was, according to well informed opinion, the best guide to tropical infectious disease to be found anywhere. He was also the best ally I could have had. I visited him often, enjoying all his hospitality except the attentions of his civet cat, which he allowed to run loose over his visitors and which enjoyed perching on my shoulders and pulling out my hair.

\section{Forewarning}

He refused to go home on leave though his leave was long overdue. He regarded the 12-18 month tours of west Africa as nonsense. Gin was the real danger to life, not malaria. The Mother Superior had been in Ibadan for nine years, and he was not going home until the war ended. He spoke soberly of a premonition that he would not survive the journey home and back. I had good reason to know what worried him when I sailed home in a slow convoy in March 1943. By June of that year, however, the submarine menace had been largely controlled because of the success of the north African campaign, and Smith's superiors literally ordered him to take home leave.

I met him in London that summer on his way back to Nigeria. I reassured him about the submarines and we had a pleasant evening together. I could not thank him enough for all he had done for me and I assured him that I had been promised a return to Nigeria in 1944. That did not happen; and Smith would not have been there to greet me. His convoy was held up outside Freetown and a stray enemy aircraft chased by the RAF threw away its bombs. One of them went down the funnel of the ship in which Smith was travelling and exploded right outside Smith's cabin. Smith was eliminated.

So his premonition was justified and the British army in Nigeria lost the most precious expert help of a truly genuine, patriotic, Irish gentleman.

\section{What are antitachycardia pacemakers and what are the indications for them?}

Antitachycardia pacemakers outwardly appear similar to atrial or ventricular demand pacemakers. The electrode and electronic circuitry must detect an atrial (or rarely ventricular) tachycardia and reliably differentiate it from sinus tachycardia. The pacemaker is then programmed to break the re-entry circuit by making myocardial cells refractory to depolarisation. This is performed by delivering timed single, multiple, or increasing numbers of electrical impulses. Programmed electrical stimulation during an invasive electrophysiological study is required to determine the most successful pacing modalities to terminate reproducably the tachycardia. Patients may be considered for an antitachycardia pacemaker if they are symptomatic from intractable recurrent arrhythmias and are intolerant or resistant to antiarrhythmic drugs. - L M SHAPIRO, senior registrar in cardiology, London. 